\title{
Film jako zajižd'ka. Ingmar Bergman jako spisovatel
}

\author{
Jan Holmberg
}

Překlad Jan a Klára Škrobánkovi

Literární tvorba Ingmara Bergmana sestává z desítek knih a stovek článků. Jistě, Bergman se plodností své tvorby nemůže rovnat Balzacovi, zároveň je ale podstatně plodnější než Flaubert. Navzdory tomu ale už během svého života - a často velmi důrazně tvrdil, že „nikdy neměl ambice stát se spisovatelem“. At’ už tomuto tvrzení věříme, nebo ne (sám doporučuji mu nevěřit), tak si musíme nejprve definovat jedno klíčové slovo. Slavnou otázku „co je to autor?" položil i zodpověděl ve svém stejnojmenném eseji Michel Foucault. Foucault datuje vznik autorství do období renesance, kdy sloužilo jako odpověd' na potřebu zajistit právo na vytváření kopií díla, ale také k vyvozování osobní zodpovědnosti autora. Výsledkem byl autor jako tvůrce, jehož díla přestala být vnímána méně sama o sobě, ale spíše jako emanující ze svého společného strůjce.

Tento přesun moci od díla k autorovi je pro Bergmana něco, z čehož jistě těžil. Veřejně ale Bergman tento stav věcí kritizoval, protože se identifikoval spíše s tvůrci kulturních artefaktů z předrenesanční doby - tedy předtím, než z těchto tvůrců renesance udělala umělce. Sám tvrdil, že by chtěl být bezejmenným řemeslníkem spíše než oslavovaným umělcem. V často citovaném eseji publikovaném na konci 50 . let, tedy v době, kdy se Bergman opravdu proslavil, sám sebe modeluje do podoby anonymního středověkého umělce. Jak jsem již řekl, tento esej („Každý můj film je mým posledním“) byl často citován, a pokud vím, nikdo neopomněl zmínit jméno jeho autora. Tak tady máte tu Bergmanovu anonymitu... Je snadné žertovat na účet Bergmanovy falešné skromnosti, když jako čerstvě světoznámý umělec začne oslavovat umělcovu anonymitu. Myslím si ale, že to myslel upřímně. Vytváří to však paradox. Bergman tvrdí, že anonymita garantuje uměleckou svobodu, jenže tato svoboda je naopak podmíněna povýšením umělce na Jméno. Právě někde v tomto rozporu můžeme najít vysvětlení toho, proč Bergman odmítal, zkoušel odmítat či předstíral pokus o odmítnutí své korunovace na autora.

Ačkoli byl Bergman zván autorem upřímně nerad, udělám vše, co mohu, abych dokázal, že se pletl.

To znamená, že se pokusím v duchu zhlédnout jeho filmy ještě před jejich vznikem, či přinejmenším odmítnout jeho vlastní náhled na filmy jako na konečný výsledek, jejichž psané originály jsou redukovány na pouhé náčrty. Ve své knize o Bergmanovi jako spisovateli (Författaren Ingmar Bergman, Norstedts, Stockholm 2018) jsem jeho texty četl jako samostatná literární díla. Filmy, pokud jsem je vůbec vzal v úvahu, pak v tomto čtení figurují jako interpretace. Sice jako autorské interpretace, ale stále jen interpretace. Koneckonců, Shakespeare byl také především divadelní manažer a režisér, který svou 
literární tvorbu pravděpodobně považoval jen za nástroj nutný k přitáhnutí publika. Se vší pravděpodobností bychom při zhlédnutí Shakespearova Hamleta v Divadle Zeměkoule okolo roku 1600 tuto inscenaci považovali za nejhorší interpretaci, jakou jsme kdy viděli. Tím chci jen říct, že mediální formy jsou historicky podmíněné a některé ještě víc než jiné. A já si myslím, že spisovatel Bergman může dokonce žít déle než filmař Bergman.

Ingmar Bergman exceluje v mnoha žánrech - jako autor esejů či memoárů, ale také deníků a dopisů. Nesmím ovšem zapomenout ani na pracovní deníky. Dnes se však ve své přednášce omezím na hlavní část jeho tvorby, a totiž na filmové scénáře. Pokud je to tedy vskutku správný termín pro Bergmanův způsob psaní, který občas až podezřele připomíná tradiční dramata, občas spíše prózu, jakou najdeme v románech, a občas dokonce i poezii. Jen málokdy ale připomíná typické filmové scénáře. Myslím, že výstižnější termín je pro tyto texty švédské slovo Filmberättelser („filmové povídky“ nebo „filmové narativy“), se kterým přišel jejich první švédský vydavatel a který vystihuje jejich vlastnosti přesahující žánr. A právě na tyto povídky se nyní budu soustředit. Vy již tyto povídky jistě znáte, ale ve své přednášce se, spíše než na jejich vztah s korespondujícími filmy nebo diskuzi ohledně jejich obecné tematiky, budu soustředit na jejich literární vlastnosti a ambice.

Filmové scénáře typicky dodržují pevnou formu danou dramaturgickými prvky, literárním stylem, nebo dokonce i typografíi. Bergman si často stěžoval, jak ho tyto požadavky omezovaly, a to alespoň do pozdních 50 . let. I tak byly jeho filmové scénáře už od počátku značně nezávislé a neobvykle, možná až nepotřebně, literární. Při prvním setkání s rytířem ze Sedmé pečeti rytiřr „otevře oči a hledí přímo proti slunci, které se vynořuje z oparu nad mořem jako nafouklá umírající ryba.“ I jako údajná inspirace pro herce a kameramana (jak Bergman vysvětluje funkci takovýchto popisů ve svých textech) je metafora slunce jako umírající ryby až příliš. Je to forma výstřednosti, která se dá připsat na účet scénáristovi, ale nikoli filmaři. V momentech, jako je tento, se spisovatel Bergman ukazuje nejen nám, ale možná i sám sobě.

Když o filmu Ingmara Bergmana řeknu, že kniha byla lepší, tak se to někomu může zdát až jako rouhání, ale v př́ípadě Hodiny vlkư si za tímto hodnocením musím stát. Tento text patří mezi to nejlepší, co Bergman napsal. O Hodině vlků bych řekl, že je téměř nevhodná pro filmovou adaptaci, at už Bergmanem nebo kýmkoli jiným. Hodina vlki̊ je knižní drama a, především, literatura - konkrétně žánru pohádkové hry. Proč? Odehrává se na pomezí mezi objektivním a subjektivním, mezi vnějším a vnitřním, mezi bděním a sněním, mezi rozumem a šílenstvím. Ač to není nemožné ukázat i na plátně, psaní nabízí jiné, jednodušší možnosti. V literatuře může postava interagovat s nespolehlivým vnějším světem, aniž by se čtenář musel jasně vymezit vůči ontologickému statusu tohoto světa. V kinematografii ale filmař potřebuje diváka navést k rozhodnutí mezi objektivní realitou a subjektivním stavem mysli. I když jsou věci nejasné, jako třeba v Personě, tak je u těchto věcí aspoň zřejmé, že jsou nejasné. V Hodině vlkư nevíme ani to. Dále pak je Hodina vlků prostě zajímavější jako kniha než jako film, nebot' je to text (kniha) o textu (Johanově deníku), ačkoli je místy těžké rozpoznat, co je co. V tomto př́ípadě Bergman píše récit po vzoru Maurice Blanchota, tedy narativ, který není narativem události ale událost samotná. 
Na úplně první straně Hodiny vlků najdeme v závorce poznámku, která se opakuje napříč textem:

\section{„(Odted' doprovázejí repliky ad libitum filmové záběry.)“}

Co proboha dělá taková poznámka ve filmovém scénáři! Bergman, jenž je často citován pro svou nedůvěru v jazyk jako takový, a zvláště pak ve své vlastní verbální schopnosti, ale který spoléhá na své audiovizuální nadání, tady uvádí obrazy jako doplněk k textu a ne naopak? A jak může probůh vzniknout film, pokud se má o výběru obrazů rozhodnout dle libosti, jak se komu zlíbí? Natáčení filmu s několikamilionovým rozpočtem vyžaduje trochu víc plánování a Bergman není zrovna znám svou ochotou improvizovat. Jak tedy máme uchopit tuto poznámku, která říká „dle libosti“? Jediné rozumné vysvětlení je, že při psaní Hodiny vlků Bergman odložil kameru a soustředil se na své psaní.

Povšimněte si prosím, že anglické vydání Hodiny vlků tyto poznámky neobsahuje. A není to jediný případ, kdy se překladatelé, redaktoři či vydavatelé, at' už měli jakýkoli důvod, rozhodli Bergmanův text „vylepšit“ tím, že z něj vyretušovali jeho výstřednosti nebo idiosynkratické využití sémantických, syntaktických či gramatických forem. Přejděme tedy k dalšímu příkladu, který se ve svých zvláštnostech od Hodiny vlků velmi liší, a totiž k Podzimni sonátě, která je př́kladem „čistého“ dramatu. Vlastně je jedním z Bergmanových nejredukovanějích, nejkompaktnějších textů. Neobsahuje v sobě téměř žádný druh instrukcí, například ke vzhledu scenérie, skoro žádné poznámky ke způsobu přednesu postavy a skoro žádnou informaci o tom, co charaktery cítí nebo co si myslí. Jen čistý a prostý dialog. Je ovšem napsán velmi vědomě. Jedna konkrétní pasáž může působit nepropracovaně či nepřipraveně, nebo dokonce jako proud vědomí (pro Bergmana velmi netypický), nicméně je vcelku působivá. Neposledně musíme vzít v úvahu, což bychom ostatně měli vždy, že byla napsána proto, aby byla spíš slyšena, než čtena. Což ale funguje velmi dobře. Navzdory tomu, že je s 207 slovy nejdelší větou ze všech Bergmanových sebraných textů, má tato pasáž rytmus vhodný pro dech, čímž svědčí o skvělé zkušenosti s přednesem psaného slova:

Sen plötsligt en dag stod dina resväskor nedanför trappan och du talade i telefonen på främmande språk, jag gick in i barnkammaren och bad till Gud att nånting skulle inträffa som förhindrade din resa, mormor skulle dö eller det skulle bli jordbävning eller alla flyg skulle få motorstopp, men du reste alltid, dörrarna stod öppna och det blåste genom huset och alla talade i munnen på varandra och så kom du fram till mig och omfamnade och kysste mig och kramade mig och kysste mig igen och såg på mig och log mot mig och du luktade gott och främmande och själv var du också främmande, du var redan på väg, du såg mig inte, jag tänkte nu stannar hjärtat, nu dör jag, så ont gör det, jag blir aldrig mera glad, det har bara gått fem minuter, hur ska jag uthärda att ha så ont i två månader och så grät jag i pappas knä och pappa satt alldeles orörlig med sin lilla mjuka hand på mitt huvud, han satt hur länge som helst och rökte sin gamla pipa, han omgav oss med rök, ibland sa han något: Ska vi gå på bio ikväll eller idag tror jag att det skulle smaka med glass till middagen. 
Mít možnost pyšnit se svým jazykem je pro Švéda vzácná př́iležitost, a tak jí chci maximálně využít. Ne proto, že bych to chtěl vám, kdo neumíte švédsky, jakkoli komplikovat, ba právě naopak, myslím si, že oproti rodilým mluvčím budete ve výhodě. K tomu ale hned přejdu. Snažím se poukázat na dvě věci: rytmus jazyka (který můžete ocenit i bez znalosti slov) a nebezpečí překladu. Protože pokud totiž nyní porovnáme tu krásnou předchozí větu s následující pasáží z anglického překladu Podzimni sonáty, přečteme si následující:

One day, your suitcases stood at the foot of the stairs. You were talking on the phone, in a foreign language. I prayed to God something would happen to stop you going away. But you always went. You came up to me, hugged and kissed me. Embraced me and kissed me again. You looked at me and smiled. You smelt so good, so strange. But you were a stranger to me. You were already on your way, you didn't see me. And so you were gone. I thought, 'Now my heart will stop. I'm going to die from the pain. I'll never be happy again. How could I endure this pain for two months?' I would cry on Father's lap. He would sit motionless, his soft little hand on my head. He'd sit there for hours, smoking his old pipe, enveloping us with smoke. Sometimes he'd speak. 'Shall we go to the cinema tonight?' 'Or, Let's have ice cream for dinner today.'

[Potom najednou jednoho krásného dne stály pod schody tvoje kufry a ty jsi telefonovala nějakým cizím jazykem, šla jsem se do dětského pokoje pomodlit k Bohu, aby se přihodilo něco, co by ti zabránilo odjet, aby umřela babička nebo bylo zemětřesení nebo se všem letadlům zastavily motory, jenže ty jsi odjela, všechny dveře byly dokořán, domem to profukovalo, všichni si skákali do řeči a pak jsi ke mně přistoupila, vzala mě do náruče, dala mi pusu, objala mě, dala mi další pusu, podívala ses na mě s úsměvem, cize jsi voněla a sama jsi byla taky cizí, byla jsi už na cestě, neviděla jsi mě, ř́kala jsem si, ted' se mi zastaví srdce, ted’ umřu, tak hrozně to bolí, už nikdy nebudu veselá, a to uplynulo teprve pět minut, jak takovou bolest vydržím dva měsíce? A potom jsem plakala tátovi na klíně, táta seděl naprosto bez hnutí, drobnou hebkou ruku na mé hlavě, seděl tak celou věčnost a kouřil starou dýmku, obklopoval nás kouřem a občas prohodil: „Nepůjdeme večer do kina?“ Nebo: „Dneska bychom si mohli po večeři dát zmrzlinu.“]

Toto je jen další příklad z řady pokusů domestikovat Bergmanův jazyk až na úroveň banality. Nejenže se překladatel snaží rozdělit tento uplakaný slovní průjem do hezkých krátkých vět, ale také používá uvozovky, aby se ujistil, že čtenář ví, kdo zrovna mluví. Kvưli tomu je celá tato pasáž nudná až na pokraj klišé, ale, co je důležitější, ukazuje nepochopení původního textu: Bergman často píše bez uvozovek, čímž jemně upomíná své čtenáře, aby zůstali pozorní: Kdo zrovna mluví? Jaká je motivace? Mám mluvčímu věřit? Uvozovky indikují, že Evina verze není přesná, zatímco bez uvozovek zůstává tato otázka nezodpovězena.

Brzy se k nejmenším detailům, jako jsou uvozovky, vrátím, ještě předtím chci ale porovnat Podzimni sonátu pro její jednoznačný a redukovaný styl s dalším scénářem ze stejného období. Zatímco scénář k Podzimni sonátě je napsaný jako úsporné tradiční drama, scénář k filmu Fanny a Alexander je napsaný jako próza, místy dokonce skoro jako román. To je zřejmé především v prologu sestávajícího z dlouhých popisů babiččina 
bytu, ve kterém Bergman rozdělil a popsal Alexandrovy smyslové vjemy jeden po druhém: nejprve nám vypravěč řekne, co protagonista vidi, tedy téměř tři strany popisující vizuální vnímání nábytku, obrazů, fotografií, světla a tmy... Dalším z řady vjemů je čich a popisy pachů jednotlivých věcí, od zelňačky až po kadibudku, stejně jako vůně lidí, tedy „symfonie vůní“ sestávajících z potu, tabáku, parfémů, pudrů, mýdla, moči atd. Nakonec představuje sluch, který je uveden žádostí o ticho - „když [člověk] stojí úplně bez hnutí a zadrží dech, uslyší ticho“ - následovanou popisy tikání hodin, škrtání per, rachocení nádobí, až výčet zvuků skončí „dlouhým a osvobozujícím zvukem“ hospodyně, která plní kamna uhlím. Můžeme tvrdit, že tyto nefilmové popisy, které je občas nemožné přenést na plátno, mají sloužit jako inspirace pro herce, scénografy, kostyméry, kamaremany atd. Ano. Navzdory tomu, co Bergman ř́ká, je to ale i literatura.

V Bergmanově tvorbě nikdy není pochyb o tom, že slova, včetně těch, která jsou vyřčena nahlas, jsou psaná. Je to jedna z věcí, za které jsou Bergmanovy filmy kritizovány, zvláště pak Bergmanovými krajany, kteří slyší, jak podivně ta slova zní. Tyto domnělé problémy s trefením se publiku do noty rozhořčily napřríklad jeho kolegu Boa Widerberga, který zvažoval, „do jaké míry vděčí Bergman za svůj úspěch zahraničním překladům svých filmů; tedy jestli dialogy postav v amerických verzích jeho filmů prostě neznějí méně podivně.“ Takovéto námitky slýcháme dodnes. Bergman ovšem není žádný realista, nikdy jím nebyl. Mluvené slovo v jeho dílech je archaické, vznešené, ale především je to psaný jazyk, spoře maskovaný za mluvené slovo. A jejich autor se velmi důkladně zajímá nejen o jejich význam, ale i o účinky jejich zvuku. Ve zvláště geniálních momentech Bergman kombinuje fonetiku se sémantikou pro dosažení výjimečných výsledků.

Například se podívejte na scénu, která je, navzdory tomu, že je nejslavnější z celé Bergmanovy tvorby, často nesprávně citována. Což je velmi jednoduché, protože je opravdu těžké slyšet, co se v ní doopravdy říká:

Who are you?

I am Death.

Have you come for me?

I have been walking by your side for a long time.

That I know.

Are you prepared?

My body is frightened, but I am not.

[Kdo jsi?

Jsem Smrt.

Přicházíš pro mne?

Chodím už dlouho po tvém boku.

Vím to.

Jsi připraven?

Mé tělo se bojí, ale já se nebojím.] 
Rytír tedy špatně interpretuje Smrt, ale kdo taky ne. Na otázku, jestli je připraven, odpovídá, že se jeho tělo bojí, ale on sám ne (ovšem ukazuje pravý opak tím, že pro strach neslyší, co je ve skutečnosti říkáno). Tyto dvě repliky v sobě obsahují několik hlavních motivů Bergmanovy tvorby: problémy komunikace, rozštěpenou osobnost, pravdu a lži... Tato scéna také ukazuje, jak Sedmá pečet', navzdory tomu, že je Bergmanovým nejproslavenějším filmem, zdůrazňuje význam psaní. Na co se ale snažím poukázat především, je to, jak si Bergman hraje s kvazihomonymitou slov rädd (bát se) a beredd (připravený) (slovní hř́ička, která se samozřejmě v překladu zcela ztrácí).

Během hádky v Lesních jahodách Marianne ironicky vyřkne „Stackars Evald.“ [Chudáčku.] Na což Evald odpovídá „Var god stackra mig inte.“ [Nech si toho chudáčka.] A o chvíli později: „Det här livet äcklar mig till kräkningar och jag tänker inte dra på mig ett ansvar som tvingar mig att existera en dag längre än jag själv vill. "[V tomhle světě se žít nedá a je tedy nesmyslné ho zalidňovat dalšími neštastníky a nejhorší ze všeho je věřit, že oni na tom budou líp než my.] Porovnejme si tato slova, nebo spíš zvuky v replikách jako „stackra mig inte“ nebo „äcklar mig till kräkningar“ s „min kropp är rädd“. Nebo takové použití nezvyklých slov v Sarabandě nebo Nevěre jako frukostera nebo nattsärk (což jsou, jak s opovržením zmiňují Bergmanovi krajané, archaické výrazy pro snídání a noční košili). Slova v Bergmanově tvorbě neslouží jen jako nositelé toho či onoho významu, nebot si Bergman dává co nejvíc záležet i na tom, jak znějí. Zkrátka se dá říci, že hromadění hrdelních hlásek zní Bergmanovi velmi vybraně.

Když britský filmový kritik David Thomson vzpomíná na své mládí v 50. letech a roli, kterou v něm měl Bergman, zmiňuje především švédštinu jako jazyk, který „kvete v našich ústech svými jemnými, zbožnými, lehce samolibými uzavřenými samohláskami a svými polykavými souhláskami. Ve tmě jsme ústy napodobovali slovo Smultronstället tak, jak jej Victor Sjöström a Bibi Andersson vyslovovali v Lesnich jahodách. “ A v časopise New Yorker Anthony Lane píše: „Není možné si splést obraz Bergmanova filmu, nebo dokonce ani jeho zvuk. Zavřete oči nebo si nevšímejte titulků a zahltí vás kolébání jeho dialogu. Může to být nesrozumitelné, ale, stejně jako operní libreto v neznámém jazyce, tu vzniká vlastní hudba a prolínání kvokání a konejšení vyřčených švédským hlasem se zdá být pro Bergmana velmi výstižné.“

Jedno z prvních promítání Sedmé pečeti v anglofonní zemi se odehrálo v Edinburgu v roce 1957 a od kritiků si vysloužilo pochvalu - nejen za film samotný, ale i za „excelentní titulky poukazující na to, že scénář byl napsán dramatickým blankversem“, z čehož vyvodili, že i když nemá „Shakespearovský důvtip“, tak se takový jazyk výborně hodí k obsahu filmu. Kritik se samozřejmě pletl. Sedmá pečet’ není napsaná v blankversu. Co chci ale říct je, že to tak občas zní. Občas člověku může neschopnost porozumět jazyku pomoci k tomu, aby lépe ocenil jeho vlastnosti. V tu chvíli tuto „záhadnou hudbu“, jak to nazývá Anthony Lane, spíš slyšíte, než chápete. Čímž se dostávám k poslednímu tématu, tedy k Bergmanovi jakožto básníkovi.

Personu sám autor nazval básní, ale básní v obrazech, nikoli ve slovech. Každopádně každý, kdo si přečte scénář, může dosvědčit, že je to i psaná poezie: „Bruset ökar i slingrande rörelser och hela ord (osammanhängande och avlägsna) börjar dyka fram likt skuggor av fiskar i ett bråddjupt vatten. "[Hučení v krouživých pohybech zesiluje a jako stíny ryb v hluboké 
vodě se začínají vynořovat celá (nesouvislá a vzdálená) slova.] Podobné kvality má i scénář k filmu Šepoty a výkřiky. Nicméně nehledě na žánr jsou Bergmanovy texty charakteristické pro silný smysl pro rytmus, rázné metafory a fonetické prvky aliterace a asonance, ve zkratce pro stejný cit pro formu a barvu jazyka, jakým disponuje i básník.

Ve své autobiografii Laterna magica věnuje autor pasáž významu a věrnosti inscenování vůči textu. $\mathrm{V}$ původním rukopise je pár vět, které byly vynechány z tištěné verze, a které jsou důležitými postřehy nejen pro Bergmana jako režiséra, ale i pro Bergmana jako spisovatele: „Interpretace je pro mě naslouchání dechu textu: Proč jsou tyto kombinace slov, tyto čárky a tyto pomlčky právě tady?“" Nejen v předváděném dramatu, ale také v literatuře - především v literatuře! - má diakritika jistý účinek. Bergman často volal po systému notačního záznamu pro film po vzoru notačního záznamu pro hudbu, ale jeden takový již existuje a jmenuje se psaný jazyk. A Bergman jej využil na maximum. V Soukromých rozhovorech najdeme konverzaci mezi Annou a její matkou. Povšimněme si rozdílné interpunkce po konkrétní opakující se spojce označené kurzívou (och je ve švédštině ekvivalent spojky $a$ ).

- Mamma! Vet du att allt går i cirkel. Det börjar med något som vi ältade i går och i förrgår och dagen innan: hur ska en präst som har förlorat sin tro kunna predika söndag efter söndag? Och: det är mitt fel att han har förlorat sin tro. Hur kan jag ta på mitt ansvar att driva honom mot sammanbrott och utarmning? Och! Han måste genast ha ett sömnmedel. Och. Om han inte somnar så är det de onda tankarna som har gripit honom och skakar honom så att han börjar gråta. Så jag måste tända lampan. Och sedan. Och sedan?

[Mami! Víš, že se všechno točí v bludném kruhu? Začíná to něčím, co jsme přetřásali včera, předevčírem i den předtím: jak má kněz, který ztratil víru, neděli, co neděli kázat? A: za to, že ztratil víru, můžu já. Jak si dokážu zodpovědět, že se kvưli mně hroutí a stává se z něj žebrák? A! Musí ihned dostat prášek na spaní. A. Jestli neusne, zmocní se ho zlé myšlenky, budou jím zmítat, až se rozpláče. Takže musím rozsvítit lampu. A potom. A potom?]

Mamma! You know, everything goes round in circles. It starts with something we went over yesterday, and the day before, and the day before that. How is it possible for a priest who has lost his faith to preach Sunday after Sunday? And . . it's my fault that he's lost his faith. How can I take it on as my responsibility to drive him into a breakdown and destitution? And . . . if he doesn't sleep, it's because those evil thoughts have taken him over and convulse him so he starts weeping. Then I have to put out the light. And then?

Za opakovaným použitím slova och, tedy českého $a$, se postupně jeden po druhém střídají interpunkční znaky. Nejprve dvojtečka, potom vykřičník a nakonec tečka. $\mathrm{Z}$ pohledu jazykovědy jen první z nich není kontroverzní. Ale jen stěží jsou to chyby. Každý z těchto tří znaků dosahuje rozdílných výsledků, sice jen sotva patrných, ale pozorovatelných. Spisovatel ví, co dělá. Nyní je porovnejme s anglickým překladem. Nejenže se překladateli ztratila celá věta („Han måste genast ha sömnmedel. “ Musí ihned dostat prášek na spaní.), ale také překládá rozsvícení světla („Så jag måste tända lampan") jako zhasnutí světla, nepovšiml si nuancí spojených s interpunkcí (a volí 
otřelé „and...“), ani těch spojených s repeticí („Och sedan. Och sedan?“), čímž celou promluvu zkazí.

Na závěr nabídnu interpretaci scén čtení v Bergmanově tvorbě. Je jich tam spousta. V Bergmanových filmech je spousta deníků, dopisů a knih. Můžeme toho říct spoustu o tom, jak Alma čte Elisabetin dopis doktorovi v Personě, nebo o tom, jak Johan usíná, zatímco mu Marianne předčítá z jeho deníků ve Scénách z manželského života, či o knize, kterou čte Izák dětem ve scénáři k filmu Fanny a Alexander, a tak dále. Já se ale zaměřím na knihu, která není jen tak nějakou knihou, ale knihou knih. I když už je na světě asi příliš mnoho analýz Sedmé pečeti, nabídnu vám ještě jednu. Navzdory tomu, jaké množství interpretací již existuje, to vypadá, že jen několik málo z nich se jakkoli zabývá tím, jak je Sedmá pečet’ také filmem o teorii médií, konkrétně pak o médiu psaní. Mělo by to být zřejmé již po přečtení titulku. Pečet čeho přesně? V Knize Zjevení se můžeme dočíst:

And I saw in the right hand of him that sat on the throne a book written within and on the backside, sealed with seven seals.

And I saw a strong angel proclaiming with a loud voice, Who is worthy to open the book, and to loose the seals thereof?

[A v pravici toho, který sedí na trůnu, spatřil jsem knihu úplně popsanou, zapečetěnou sedmi pečetěmi. Tu jsem viděl mocného anděla, který vyhlásil velikým hlasem: „Kdo je hoden otevřít tu knihu a rozlomit její pečetě?"] (Bible. Zjevení 5.1-2)

Krom toho, že je raným př́kladem metaliteratury, je Kniha Zjevení také nejpodivnější z knih v celé bibli. Z literárního hlediska není o nic méně fascinující, když zjistíme, že tak sugestivně vylíčený svitek není nic jiného než to, co Alfréd Hitchcock nazval McGuffin ${ }^{1}$. Sedm pečetí se láme jedna po druhé, uvolňující záhadné jezdce na koních, zemětřesení a troubící anděly. Nikde ale není odhaleno, co je na svitcích napsáno. Hlavním odkazem v Sedmé pečeti je tedy kniha o knize, kterou nikdo nečte. Jako taková je tedy skvělým příkladem Bergmanova rozpolceného vztahu k psaní, které je ztěží čitelné, nespolehlivé nebo zprostředkovatelem nežádoucích informací. Jen stěží může být náhoda, že hrdinové Sedmé pečeti jsou kočovní herci, kteří se vyjadřují pomocí svých představení, nikoli psaním. Se vší pravděpodobností ani neumějí číst.

\section{Poznámka k překladu}

V textu jsou použity překlady Josefa Vohryzka (publikováno pod jménem Jiří Osvald) (Sedmá pečet), Dagmar Hartlové (Lesni jahody) a Zbyňka Černíka (Fanny a Alexander, Hodina vlkư, Soukromé rozhovory, Persona, Podzimni sonáta).

Překlad Bible: Bible. Písmo svaté starého a nového zákona. Ekumenický překlad, Praha: Ústřední církevní nakladatelství, 1985, str. 236.

1 Pozn. překladatele: McGuffin je ve filmu nejčastěji předmět, kolem kterého se točí celý příběh, přestože on sám nemá na vývoj zápletky vůbec žádný vliv. kufř́ik v Tarantinově filmu Pulp Fiction. 


\section{Česká vydání zmiňovaných Bergmanových textů:}

Fanny a Alexander (BERGMAN, Ingmar. Fanny a Alexander. Praha: Mladá fronta, 1988.)

Hodina vlků (BERGMAN, Ingmar. Hodina vlků. Praha: Kniha Zlín, 2018.)

Lesni jahody (BERGMAN, Ingmar. Filmové povidky. Praha: Odeon, 1982.)

Persona (BERGMAN, Ingmar. Šepoty a výkřriky. Praha: Paseka, 2000.)

Podzimni sonáta (BERGMAN, Ingmar. Šepoty a výkřiky. Praha: Paseka, 2000.)

Sedmá pečet' (BERGMAN, Ingmar. Filmové povídky. Praha: Odeon, 1982.)

Soukromé rozhovory (BERGMAN, Ingmar. Soukromé rozhovory. Praha: Volvox Globator, 1997.) 
